\begin{tabular}{|lcc|}
\hline & Osmanlı Medeniyeti Araştırmaları Dergisi & Journal of Ottoman Civilization Studies \\
e-ISSN 2458-9519 & Cilt 6, Sayı 11, Ekim 2020 \& Vol 6, No 11, October 2020 \\
DOI: $10.21021 /$ osmed.788905 & Makale Türü: Araştırma Makalesi & Article Types: Research Article \\
\hline Geliş Tarihi \& Received: 01.09 .2020 & Kabul Tarihi \& Accepted: 15.10.2020 & OSMED, 2020, 6(11): 232- 243
\end{tabular}

\title{
Osmanlı Devleti’nin Son Döneminde Eytâm Malları Üzerinde Yapılan Usulsüzlükler ve Bu Usulsüzlüklere Karşı Alınan Tedbirler
}

\author{
Irregularities Made Against Artifacts and Measures Taken Against These Irregularities in the \\ Last Period of the Ottoman Empire
}

Necla KIZILDAĞ $\breve{G}^{*}$

$\ddot{O} z$

Tarih boyunca toplumların devletlerin temel hedeflerinden biri, ekonomik ve sosyal bakımdan farklı mensuplarının adil ve insanca yaşamalarını sağlamaktır. Bu ortamın sağlanması, mümkün olduğunca tüm fertlerin ihtiyaçlarının karşılanmasına bağlıdır. Toplum içinde mutlak anlamda desteğe ve korumaya ihtiyacı olan gurupların başında yetim çocuklar gelmektedir. Keza Kur'an-ı Kerîm'in vahyi öncesinde cahiliye toplumunda görülen adaletsizliklerin başında yetimlere haklarının verilmemesi mevcuttur. Kur'ân-1 Kerîm'de, toplumdaki yetim algısını, yetim-toplum, yetim-vasî münasebetini yeniden düzenlemiştir. Aynı zamanda, yetimlerin haklarının gözetilmesi gerektiğini ifade eden birçok hadis-i şerifler mevcuttur.

Çalışmada ele alınacak olan Eytâm Sandıkları, XIX. Asırda yürürlüğe girmiş sosyal hizmet kurumlarından birisidir. yetimler için tesis edilmiş bu müessese, zamanla kötü niyetli idarecilerin eline geçerek bozulmaya başlamıştır. Çalışmanın amacı İslam dininde yetim hakkının önemini zikretmek, bu önemi Osmanlı Devleti’nin kurumuyla somutlaştırmak ve görevini kötüye kullanan idarecileri gün ışı̆̆ına çıkarmaktır. Ayrıca yetim malları ile ilgili meydana çıkan olumsuzlukları ortadan kaldırmak adına devletin yayımladığı nizamnameler zikredilmiştir. Devlet, farklı zamanlarda yayımladığı nizamnameler ile mallar üzerindeki her türlü olumsuzluğa karşı tedbir almaya çalışmıştır.

Anahtar Kelimeler: Kur’an, Osmanlı Devleti, Eytâm, Yetim, Sandık.

\begin{abstract}
Throughout history, one of the main goals of states and societies is to ensure that members of different economically and socially different lives live fairly and humanely. Providing this environment depends on meeting the needs of all individuals as much as possible. Orphan children are among the groups that absolutely need support and protection in society. Likewise, before the revelation of the Quran, orphans are not given their rights at the beginning of the injustices seen in the ignorant society. In the Quran, the perception of orphans in the society, orphans-society, orphans-guardian relations are rearranged. At the same time, there are many hadiths stating that the rights of orphans should be observed.

Eytâm Chests to be dealt with in the study, XIX. It is one of the social service institutions that came into force in the century. This institution, which was established for orphans, fell into the hands of malicious administrators and started to deteriorate. The aim of the study is to mention the importance of the right of orphans in the religion of Islam, to concretize this importance with the institution of the Ottoman State and to bring to light the rulers who abused their duties. In addition, regulations issued by the state were mentioned in order to eliminate the negativities regarding orphan properties. The state tried to take measures against all kinds of negativity on the goods with the regulations published at different times.
\end{abstract}

Keywords: Qur'an, Ottoman State, orphans Orphans, Fund.

*(Dr. Öğrencisi); Afyonkocatepe Üniversitesi, neclakizildag26@gmail.com; ORCID:orcid.org/0000-0003-2781-7590

Kaynak Gösterme: Kızıldağ, N. “Osmanlı Devleti’nin Son Döneminde Eytâm Malları Üzerinde Yapılan Usulsüzlükler ve Bu Usulsüzlüklere Karşı Alınan Tedbirler". Osmanlı Medeniyeti Araştırmaları Dergisi, 6 (2020): 232-243. 


\section{Giriş}

İslam alan yazınında "hak" kelimesi, anlam itibari ile bâtılın zıttı olarak kabul edilmekle beraber, hukuk alanında kişilere tanınan menfaat ve yetkiler bütünü anlamına gelir ${ }^{1}$. Kur'ân-1 Kerîm'in pek çok ayetinde insan hakkı, anne baba hakkı, çocuk hakkı, yetim hakkı ve keza hak kelimesinin zıddı olarak haksızlık gibi konular dikkat çekmektedir.

Arapça kökenli bir kelime olan yetim; babasını kaybeden çocuk için kullanılmaktadır². Öksüz kavramı ise annesi veya hem annesi hem de babası ölmüş çocuklar için kullanılmaktadır ${ }^{3}$. İslam dininde çocuğun yetiştirilmesiyle alakalı anne ve babaya önemli sorumluluklar yüklenmiştir. Ancak anne ve babası olmayan yetim ve öksüz çocuklar için de bu sorumluluklar, tüm topluma ve devlete görev olarak verilmiştir'. Kur'an1 Kerim'de on iki surede olmak üzere toplam yirmi üç yerde tekil veya çoğul olarak yetim kelimesi zikredilmektedir 5 .

İslam dini yetimlere ihtimam göstermeyi sosyal bir gereklilik olarak algılamıştır. Buna bağlı olarak İslam kurallarına göre varlığını sürdüren Osmanlı Devleti de bu sosyal gerekliliği karşılayan müesseseler teşkil etmiştir ki bunlardan ilk akla geleni şüphesiz vakıflar olacaktır ${ }^{6}$. Vakıflar, Osmanlı sosyo-ekonomik yapısını şekillendiren en önemli kurumlardan biridir. Kişinin doğumundan ölümüne kadar olan her safhada o konuyla ilgili bir vakıf bulmak mümkündür. Osmanlı Devleti'nde tamamen hayır maçlı kurulan bu yapıların içinde yetim ve kimsesizler için kurulan vakıflar önemli bir yer teşkil etmektedir. Çok yönlü olan vakıfların farklı uygulamaları olarak karşımıza çıkan mahalle ve köylerdeki avârız vakıfları, toplumun esnaf kesimine yönelik oluşturulan esnaf sandıkları, yeniçerilere yönelik orta sandıkları gibi kuruluşların ilgili bölgelerde yetimlere yönelik ciddi destek olduklarını, yetim çocuğun gündelik ihtiyaçlarının yanında barınma ve eğitim alanına kadar uzanan geniş yelpazede faaliyet yürüterek ciddi fonlar oluşturduklarını belirtmemiz gerekir ${ }^{7}$

Temelleri 1863 y1lında atılan ve günümüzde de hizmetlerine devam eden Darüşşafakalar, yetim ve öksüz çocukların ihtiyaçlarını karşılamaktadır. Onun bir nevi devamı olma özelliğinde olan Darüleytâmlar da 1915 yılından itibaren yetimlerin barınması başta olmak üzere diğer pek çok zaruri ihtiyacını karşılamaktadır ${ }^{8}$. Yetim mallarının muhafazası ve işletilmesi için kurulan diğer kurum Eytâm Sandıklarıdır.

Yetimler ve Eytam Sandıkları ile ilgili çalışmalar İslam Hukuku ve Tarih ilmi alanında olmuştur. İslam Hukuku alanında yapılanlar genellikle yetimleri koruma ve mallarını muhafaza etme temelleri üzerinedir. Tarih alanında ise eytâm sandıkları ve kurumsal hali olan Emval-i Eytâm İdaresinin işleyişi olup konu ahlaki olarak değerlendirilmemiştir. İkincil kaynaklar olarak değerlendirdiğimiz tezler ve makaleler konuyu

${ }^{1}$ Muhsin Demirci, "Açılış Konuşmaları", Kur'ân ve Sünnete Göre Temel Insan Hakları, haz., İsmail Kurt ve Seyit Ali Tüz (İstanbul: Ensar Neşriyat, 2014), 11.

2 Abdüsselam Arı, "Yetim", Diyanet Vakfı İslam Ansiklopedisi, XLIII (İstanbul 2013), s. 501.

${ }^{3}$ Asiye Mevhibe Coşar, "Türk Söz Varlığında "Öksüz" ve "Yetim” Kavramları", Savaş Çocukları, Öksüzler ve Yetimler, (İstanbul: Kişisel Yayınevi, 2003), 297.

4 Nesimi Yazıcı, "Osmanlılarda Yetimlerin Korunması Üzerine Bazı Değerlendirmeler", Ankara Üniversitesi Ilahiyat Fakültesi Dergisi 48/l, (2007): 4.

5 Bakara, 2/83-177-215-220, Beled, 90/15, Duha, 93/6-9, Enfâl,8/41, En'am, 6/152, Fecr, 89/17, Haşr, 59/7, Kehf, 18/82, İsra,17/34, Nisa, 4/2-3-6-8-10-36-127 iki defa, Maûn, 107/2, İnsan, 76/8.

6 Necla Kızıldağ, "Eytâm İdaresi ve 50 Nolu Eskişehir-Sivrihisar İdanat Sandığı Defterinin Transkripsiyonu ve Değerlendirmesi", (yüksek lisans tezi, Afyon Kocatepe Üniversitesi, 2019), 1.

7 Tahsin Özcan, Osmanlı Para Vakıfları: Kanûnî Dönemi Üsküdar Örneği, (Ankara: Türk Tarih Kurumu Yayınları, 2003), 80-86.

8 Tahsin Özcan, “Osmanlı Yetiminin Hamisi”, Yoksulluk 3, (İstanbul: Deniz Feneri Yayınları, 2003), 34. 
bölgesel olarak ya da sınırlı şekilde ele almışlardır. Eytâm İdaresi ile ilgili ilk olarak en geniş bilgi Veli İnanç'ın Eytâm İdaresi-Sandıkları ve Marmaris Örneği (1885-1911)9, adlı tez çalışmasında karşımıza çıkmaktadır. Eytâm idaresinin tarihi süreci ile Marmaris Eytâm Sandığı ile konu bölgesel olarak değerlendirilmiştir. Bu çalışmadan sonra benzer özelliklerde İrfan Ünal 167 Nolu Çanakkale Eytâm Sandığına Mahsus Teminatlı İdâne Defteri'nin Transkripsiyonu ve Değerlendirmesi (1920-1926) ${ }^{10}$, Abdullah Taha Yıldız Kâtip Seyyid Mehmed Nuri Efendi'nin Eytâm Sicillerine Göre Osmanlılarda Yetim Mallarının İdaresi ${ }^{11}$, Necla Kızıldağ Eytâm İdaresi ve 50 Nolu Eskişehir-Sivrihisar İdanat Sandı̆̆ Defteri'nin Transkripsiyonu ve Değerlendirmesi ${ }^{12}$ gibi yüksek lisans çalışmaları örnek olarak gösterilebilir. Konuyu bölgesel almak dışında genel manada Eytâm Sandıkları ve Eytâm İdaresi'ni ele alan makale çalışmaları da mevcuttur. İsmail Hızal İlk Sosyal Güvenlik Birimlerinden Eytâm Sandıkları ${ }^{13}$, Mehmet Çanlı "Eytâm İdaresi ve Sandıkları (1851-1926)" ${ }^{14}$, Mehmet Çanlı, Eytâm İdaresi- Sandıkları ve Osmanlı Devleti'nde Yetimlerin Ekonomik Haklarının Korunmast ${ }^{15}$, Tahsin Özcan Osmanlı Toplumunda Yetimlerin Himayesi ve Eytâm Sandıkları ${ }^{16}$, Fatih Bozkurt Yetimi Kolla, Malını Koru! Tereke Defterleri Ve Yetim Malları (1785-1875) $)^{17}$, ve güncel örnek olarak Ahmet Ekşi, Şer'iyye Sicilleri Örneğinde İslâm Hukuku Bakımından Evlat Edinme ${ }^{18}$ adlı çalışmalar zikredilebilir.

Yetimlere ait malları muhafaza edip, yetim çocuk rüşd/büluğ yaşına gelene kadar bu mal üzerinde borç para ihtiyacı olanlara belli nema oranlarıyla borç vermesi, işletilmiş parayı çocuğun rüşd yaşına gelene kadar hayata hazırlamasını amaçlayan eytâm sandıkları, uzun yıllar Osmanlı ekonomik, sosyal hayatını şekillendiren yapılardan biri haline gelmiştir ${ }^{19}$.

Söz konusu müessese başkent İstanbul'dan sonra devletin tüm yerleşim yerlerinde kendini göstermeye başlamıştır. Sandıkların fonksiyonu geniş coğrafyalara yayıldıktan sonra belli kurallar çerçevesinde devlet kontrolü sağlanmaya çalışılmıştır. Devlet bu kontrolü belli tarih aralığında yayımladığı nizamnameler ${ }^{20}$

9 Veli İnanç, "Eytâm İdaresi-Sandıkları ve Marmaris Örneği (1885-1911)", (yüksek lisans tezi, Muğla Üniversitesi, 2002).

10 İrfan Ünal, "167 Nolu Çanakkale Eytâm Sandığına Mahsus Teminatlı İâne Defteri'nin Transkripsiyonu ve Değerlendirmesi (1920-1926)", (yüksek lisans tezi, Çanakkale On Sekiz Mart Üniversitesi, 2010).

${ }^{11}$ Abdullah Taha Yıldız, "Kâtip Seyyid Mehmed Nuri Efendi’nin Eytâm Sicillerine Göre Osmanlılarda Yetim Mallarının İdaresi", (yüksek lisans tezi, Marmara Üniversitesi, 2017).

12 Kızıldağ, a.g.t.

13 İsmail Hızal, "ilk Sosyal Güvenlik Birimlerinden Eytâm Sandıkları”, (IV. Afyonkarahisar Araştırmaları Sempozyumu Bildirileri 29-30 Eylül 1995): 286-291.

${ }^{14}$ Mehmet Çanlı, "Eytâm İdaresi ve Sandıkları (1851-1926)”, Türk Ansiklopedisi, XIV, (Ankara 2002), s. 57-73.

${ }^{15}$ Mehmet Çanlı, "Eytâm İdaresi- Sandıkları ve Osmanlı Devleti’nde Yetimlerin Ekonomik Haklarının Korunması", Emine Gürsoy-Naskali, Aylin Koç (editörler), Savaş Çocukları: Öksüzler ve Yetimler, (İstanbul 2003), 59-86.

16 Tahsin Özcan, “Osmanlı Toplumunda Yetimlerin Himayesi ve Eytâm Sandıkları”, Istanbul Üniversitesi Ilahiyat Fakültesi Dergisi, 14, (2006): 103-121.

17 Fatih Bozkurt, "Yetimi Kolla, Malını Koru! Tereke Defterleri Ve Yetim Malları (1785-1875)", Trakya Üniversitesi Edebiyat Fakültesi Dergisi, 3, (2012): 69-90.

${ }^{18}$ Ahmet Ekşi, Şer'iyye Sicilleri Örneğinde İslâm Hukuku Bakımından Evlat Edinme, (İstanbul: Ensar Neşriyat, 2019).

${ }^{19}$ Kızıldağ; a.g.t., 3

20 Düstur, Tertip 1, "Eytâm Nizamnâmesidir 1", 270-275, Düstur, Tertip 1, Cilt 4, 92, Düstur, Tertip 1, "Memâlik-i Mahruse-i Şahânede Küşâd Olunacak Eytâm Sandıklarının Sûret-î İâre ve Muhafazâsı Hakkında Nizamnâme 1", 276281, Düstur, Tetip 1, "Bâ İrâde-i Seniyye Teşkil İden Meclis-i İdâre-i Emvâl-i Eytâmın Sûret-i Teşkîlini ve Vezâifini Mübeyyin Nizâmnâmedir 3", 551, Düstur, Tertip 1, "İnfâk-ı Muhtâcin-î Eytâm ve Erâmil-î illmîye Nizamnâmesidir" 552554, Düstur, Tertib 1, "Telgraf ve Posta Memurîn ve Ketebe Hademesinden Tekâüde Şâyeste Bulunanların Derece-i İstihkâklarına ve Bunların Eytâm ve Erâmilinin Mertebe-i İhtiyâclarına Göre Tahsis Kılınacak Maaşlar ve Buna Karşılık 
doğrultusunda kurallara bağlanarak teşkilatlı bir fon haline getirmiştir. Söz konusu nizamnamelerde sandıkların tarihi süreci ve işleyişinin yanında yetimlerin mallarından sorumlu eytâm müdürleri, naib, kadı gibi görevlilerden de bahsedilmiştir. Nizamnameler değerlendirilip müessese hakkında ortaya çıkarılan bilgiler tarih ilmine büyük katkılar sağlamıştır. Ancak nizamnamelerde sorumluluklarından bahsedilen eytam müdürleri, naib, vasi gibi kişilerin yetkilerini kötüye kullanarak usulsüzlük yaptıklarını gösteren müstakil bir çalışma yapılmamıştır.

Eytâm sandıklarında geniş yetkilere sahip olan eytâm müdürleri, naibler, vasiler gibi kişilerin görevlerinde yaptıkları usulsüzlükler ve aldıkları cezalar kayıt altına alınmıştır. Bu kayıtlar çerçevesinde öncelikle Kur'an'da yetim/öksüz hakları ve eytâm müdürlerinin bu haklar üzerinde şahsi menfaatlerini düşünerek yaptıkları usulsüzlüklerden bahsedilecektir.

\section{Kur'ân-ı Kerîm'de Yetim ve Vasî Kavramları}

İslam dininin yetimlere ilgili hassasiyeti Kur'ân-1 Kerîm'de açıkça görülmektedir. Bu bağlamda Hz. Peygamberin de yetim olması önemli bir etkendir"21. Ebû Hureyre Hz. Muhammed (s.a.s.): "Yedi helak edici günahtan kaçınınız” buyurdu. Yanındakiler, "Ey Allah'ın Resûlü, bunlar nelerdir?" Dediklerinde Hz. Muhammed, “Allah'a ortak koşmak, sihirle uğraşmak, ölümü hak eden hariç Allah'ın yasaklamış olduğu cana klymak, faiz yemek, yetim mall yemek, düşmana hücum sirasında geri kaçmak, namuslu ve hiçbir şeyden habersiz mümin kadınlara zina iftirasında bulunmak” buyurdu demiştir ${ }^{22}$.

Yetimler sosyal hayatın bir parçasıdır. Onları himaye edip toplum içinde sağlıklı birey olmalarını sağlamak şüphesiz hepimizin görevidir. Nitekim Kur'an-1 Kerim'de Allah şöyle buyurmaktadır: Dünya ve ahiret hakkında (lehinize olan davranışları düşünün ve ona göre hareket edin). Sana yetimler hakkında soruyorlar. De ki: Onlarl iyi yetiştirmek (yüz üstü bırakmaktan) daha hayırlıdır. Ĕger onlar ile birlikte yaşarsanız, (unutmayın ki) onlar sizin kardeşlerinizdir. Allah, işleri bozanla düzelteni bilir. Ĕ̆gr Allah dileseydi, sizi de zahmet ve meşakkate sokardl. Çünkü Allah güçlüdür, hakîmdir ${ }^{23}$. Sosyal dayanışmanın ehemmiyetini gösteren bu ayette yetimler özellikle belirtilmiştir.

Kur'an-1 Kerim'de yetim konusu en çok Nisa Suresinde işlenmektedir ${ }^{24}$. Burada yetim ve öksüzlerin mallarına ihtimam göstermeye ${ }^{25}$, onlara iyiliklerde bulunmaya ${ }^{26}$, çocuk rüşd yaşına geldiğinde malları konusunda neler yapılması gerektiğine ${ }^{27}$, yetim mallarında haksızlık yapanların cezalandırılacağına ${ }^{28}$ ve kız çocuklar konusundaki evlilik münasebetine ${ }^{29}$ vurgu yapılmaktadır. Ĕger yetim klzlarla evlendiğinizde onlara karşı adaletli davranamamaktan korkarsanız, hoşunuza giden diğer kadınlardan iki, üç ve dörde kadar evlenebilirsiniz. Ĕger adaleti gözetmemekten korkarsanız, o zaman bir tane ile veya elinizin altındakiyle yetinin. Doğruluktan ayrllmamak için bu daha elverişlidir ${ }^{30}$. Ayet-i Kerimesi indikten sonra Müslümanlar, Hz. Muhammed (s.a.v.)'den kadınlar hususunda nasıl davranacakları dair sorular sormaya

Tutulacak Mebâliğin İâre-i Mahsûsasına ve Bu Bâbda Lâzım Gelen Muâmelâta Dair Nizamnâmedir 3", 554-561, Düstur Tertip 1, "Umum-u Emvâl-i Eytâmın Suret-i İdaresi Hakkında Tadilen Kaleme Alınan Nizamnamedir 8", 515-548.

${ }^{21}$ Mehmet Şirin Ayral, “Kur’an'ın Yetimlere Bakış Açısı”, (yüksek lisans tezi, Selçuk Üniversitesi, 2007$), 13$.

22 Sahîh-i Buhârî, Muhtasarı Tecrîd-i Sarîh, çev., Abdullah Feyzi Kocaer, (İstanbul: Turkuaz, 2013), 559.

23 Bakara, 2/220.

${ }^{24}$ Nisa, 4/2-3-6-8-10-36-127.

25 Nisa, 4/2,127.

${ }^{26}$ Nisa, 4/8-36.

27 Nisa, 4/6.

${ }^{28}$ Nisa, 4/10.

${ }^{29} \mathrm{Nisa}, 4 / 3$.

30 Nisa, 4/3. 
başladılar. Bunun üzerine Yüce Allah: Senden kadınlar hakkında fetva istiyorlar. De ki: "Onlara ait hükmü Allah size açıklıyor: Kendilerine yazılmış olanı (mirası) vermediğiniz ve evlenmek istemediğiniz yetim kadınlar hakkında, kimsesiz çocuklar hakkında, yetimler için adaleti getirmeniz hakkında, size bu kitapta okunan ayetler vardır ${ }^{31}$. Kendilerine yazlmış olanı miras vermeyip evlenmek istemediğiniz yetim kadınlar buyurması, gözetimi altında bulunan yetim kızın yalnızca güzelliği ve malı için evlenmek isteyenlere bu evliliğin yasaklandığını belirten bir ayettir ${ }^{32}$.

Yetim ve öksüz çocuklar kendilerini savunan ebeveynlerinden yoksun oldukları için sosyal hayatta savunmasızdırlar. Bu noktada ebeveynlerinden kendisine intikal eden malları var ise bunları kullanırken zorluk çekeceklerdir. Zira yaşları ve tecrübesizliklerinden dolayı başkasının yardımına ihtiyaçları olacaktır. Şüphesiz bu malları kendi menfaatleri için kullanacak insanlar olabilir. Allah yetim ve öksüzlerin mallarına yapılacak kötü muamelelerden bizleri menetmiş ve onların mallarını zamanı geldiğinde adaletli şekilde teslim etmeyi emretmiştir ${ }^{33}$.

İslam Tarihinde Hz. Peygamber döneminden itibaren ebeveynlerden birinin veya ikisinin ölümü ya da ayrılık sebebiyle ailenin yıkılması halinde, çocukların bakımı, korunması, terbiyeli şekilde eğitilmesiyle alakadar olacak bir kişi görevlendirilmiştir. Burada çocuğun bedenen ve ruhen sağlıklı bir birey olması hedeflenmiştir. Çocukla ilgili belirli hak, yetki ve sorumluluk sahibi bu kişiye hidane adı verilmektedir ${ }^{34}$. Osmanlı devletinde ise bu kişinin adı vasî̀'dir.

Her şeyden önce hidâne/vasî olacak kimsenin güvenilir olması gerekmektedir. Yetim çocuğun malları üzerinde yükümlülüklerini yerine getirmeyenlere hâkim tarafından müdahale edilmektedir. $\mathrm{Bu}$ durum ayette Velîsi bulunduğunuz yetimleri evlilik çağına varıncaya kadar gözetip deneyin. Ĕger onların akılca olgunlaşıp kâr-zararı ayırt edebilecek bir duruma ulaştıklarına kanaat getirirseniz, o takdirde mallarını kendilerine hemen devredin. Büyüyecekler de malların elimizden alacaklar diye o malları israf ile ve tez elden yiyip tüketmeyin. Zengin olan velî, yetim malına tenezzül etmesin; muhtaç olan da ihtiyaç ve emeğine uygun olarak meşrû ölçüde bir şey yesin. Mallarını kendilerine teslim ettiğinizde de yanlarında şâhit bulundurun. Hesap sorucu olarak Allah yeter ${ }^{35}$. Şeklinde belirtilmiştir.

Yetimin mallarını verme zamanı Kur'an-1 Kerim'de rüşd yaşına gelince ifadesiyle gösterilmektedir. Rüşd, sözlükte doğru yolu bulmak, makul davranmak anlamına gelir. Ayetlerde belirtilen yönü ise yetimin malını din, akıl, mantık, iktisat alanlarında uygun bir biçimde koruyup harcamasını sağlayan fikrî olgunluğa sahip olma yetisidir ${ }^{36}$. Ayette geçen rüşd üç şekilde yorumlanmaktadır: akıl, düzgünlük (akıl ve din düzgünlüğü) ve malı düzgün kullanma. Bu özellikleri karşılayabilen rüşd yaşının kaç olması konusunda farklı görüşler ${ }^{37}$ olmakla birlikte 1824 tarihli Osmanlı Emval-i Eytâm Nizamnâmesinde yetimlere ancak 20 yaşından sonra sandıktaki mallarının teslim edileceği hükme bağlanmıştır ${ }^{38}$.

\footnotetext{
31 Nisa, 4/127.

32 Ömer Güler Özsoy, İlhami, Konularına Göre Kur'an (Sistematik Kur'an Fihristi), (Ankara: Fecr, 2017), 258.

${ }^{33}$ Konu ile ilgili ayetler için bakınız: Nisa, 4/2-6-10-177, En’am, 6/152, Kehf, 18/10, İsra, 17/111, Enfal, 8/75.

${ }^{34}$ Ali Bardakoğlu, "Hidâne", Diyanet Vakfı İslam Ansiklopedisi XVII (İstanbul 1998), s. 476.

${ }^{35}$ Nisa, 4/6.

${ }^{36}$ Saffet Köse, "Rüşd", Diyanet Vakfı İslam Ansiklopedisi XXXIV (İstanbul 2008), s. 298.

${ }^{37}$ Ebû Hanife, rüşd yaşının kızlarda17, erkeklerde 18 olduğu görüşündedir. Bu görüşün aksine İmam-ı Âzam akılı bir kimse en fazla 25 yaşına kadar beklenir o yaşta bir kimse reşid olmasa da malı kendisine teslim edilir demiştir. Konu ile ilgili ayrıntılı bilgi için bakınız: Vecdi Akyüz, "Kur'an ve Sünnette Ebeveyn ve Çocuk Hakları”, Kur'ân ve Sünnete Göre Temel Insan Hakları, haz., İsmail Kurt ve Seyit Ali Tüz (İstanbul: Ensar Neşriyat, 2014), 343.

${ }^{38}$ Akyüz, a.g.m., 343.
} 
İslam Tarihi boyunca birçok dini uyarılara ve yasal tedbirlere rağmen yetim malları üzerinde çeşitli yollarla hileler yapan kişiler bulmak mümkündür. Bu durum günümüz toplumlarının da karşılaştığı bir meseledir. Yetim hakkından sorumlu vasiler, çeşitli yollarla her türlü hileleri yapmışlar, yapmaya da devam etmektedirler. Seyyid Kutup, Fi Zilal 'il-Kur'ân, adlı eserinde, yetim malları üzerinde yapılan usulsüzlükler konusunu modern cahiliyede de görmenin mümkün olduğunu, yetimlere ait malları üzerinde usulsüzlük yapanlara kanunların ve yaptırımların bir yararı olmayacağını, tek yararın takva ve vicdanlar üzerindeki içsel gözetimin olduğunu belirtmiştir ${ }^{39}$.

Müslüman devletlerin tümünde yetimlere sahip çıkmak, onların haklarını yememek, onları topluma kazandırarak sağlıklı bireyler olmalarını sağlamak sosyal ve dini gereklilik olarak algılanmıştır. Bu bağlamda tarihteki pek çok İslam devleti, yetim çocukları da kapsayan sosyal hizmetler yürütmeye başlamışlardır. Hz. Peygamber ile başlayan sosyal devlet çerçevesindeki faaliyetler, daha sonraki dönemlerde de sistemli halde devam etmiştir. Özellikle Hz. Ömer kendi yönetimi döneminde sosyal hizmetlerde kurumsallaşmaya önem vermiş, Emeviler ve sonraki İslam devletlerinde pek çok kurum açılarak sosyal hizmet uygulamaları güçlü bir ivme kazanmıștır. Abbasiler dönemi ve sonrasında da Türklerin İslamiyet'e dâhil olmaları ile birlikte sosyal hizmetler hızlı bir gelişim göstermiştir. Özellikle Osmanlı Devleti, söz konusu ayetler ve hadisler çerçevesinde hem sosyal hem de ekonomik bağlamda yarar sağlayan farklı kurumlar tesis etmiştir. Bu tesislerden en önemlilerinden biri çalışmamıza konu olan Eytâm Sandikları'dir.

\section{Eytâm Sandıklarının Menşei}

Osmanlı toplumunda yetim kalan çocuğu koruma altına alma, onlara şefkatli şekilde yaklaşma, mallarını tasarruf edemeyenlere yetimlere vasî tayin etme, sosyal ve dini gereklilik olarak benimsenmiştir.

Osmanlı Devleti'nde padişah, belli bir toplum veya şahıs tarafından kurulan vakıflar, yardıma muhtaç olanları, yolda kalmışları, yetimleri, kimsesiz çocukları himaye etme ve onların ihtiyaçlarını karşılamak için çalışmıştır. Osmanlı Devleti geniş yelpazeye sahip olan vakıfların yanında kendine özgü bir şekilde doğrudan yetimlere ait özel kurumlar kurmuştur. Kimsesiz çocukların yeme, içme, barınma gibi temel ihtiyaçlarının yanında onları yetiştirip topluma kazandırmak amacıyla çeşitli fonlar oluşturulmuştur. Eytâm Sandıkları olarak adlandırılan bu fonların ne zaman kurulduğu bilinmemektedir. Başlangıçta ferdi olarak uygulanıp zamanla kurumsal bir hüviyet kazanarak yetim çocukların ebeveynlerinden kalan malları işletip hem çocuğu hayata hazırlamak hem de nakit para ihtiyacına sahipler için bir kredi imkânı sunmak gibi karakteristik bir ekonomi anlayışıyla oluşturulan Eytâm Sandıkları, derinden incelemeye değer bir konu olarak karşımıza çıkmaktadır ${ }^{40}$.

Eytâm sandıkları ya da keseleri diye adlandırılan bu fon, İslam dininin de emrettiği üzere yetimlerin ebeveynlerinden miras kalan menkul ve gayr-î menkul mallarının vasîleri tarafından işletilerek kontrol altına alması, yetim çocuğun ihtiyaçlarını da kontrol ederek harcaması, reşit olduklarında ise işletilmiş malı çocuğa teslim ederek onu hayata başlatması amacıyla kurulmuştur. Mezkûr sandıklar iki şekilde teşekkül ettirilmiştir. Birincisi, babanın vefat etmeden önce bir vasîyi miras işleri ve ölümünden sonra çocuklarının

\footnotetext{
${ }^{39}$ Seyyid Kutup, Fi Zilal'il-Kur'ân 14, çev., M.Emin Saraç, i. Hakkı Şengüler ve Bekir Karlıăa, (ìstanbul: Hikmet Yayınları, 1979), 382.

${ }^{40}$ Ahmet Eryüksel, “Osmanlı Devleti'nde Dul ve Yetimler", Şarkiyat Mecmuası, VIII, (1998): 331
} 
mal varlığı konusunda vazifelendirip bunu kadı önünde tasdik etmesiyle, ikincisi babanın herhangi bir vasî tayin etmeden ölmesi halinde bölge kadısının vasî tayin etmesiyle sandığın oluşturulmasıdır ${ }^{41}$.

Özcan bu konu üzerinde yaptığı araştırmalarda yetim çocuğun rüşd yaşına gelinceye kadar tüm temel ihtiyaçları kendi malından, vasînin denetiminde karşılandığını fakat geçen zamanda paranın değer kaybetmesi tehlikesine karşı bu malların boş durması yerine nakit para ihtiyacında olanlara ortalama \%10$\% 20$ arasında bir vade farkıyla borç verildiğini, bu işlemlerin ise gerek İstanbul'da gerekse taşralardaki mevcut mahkemelerde müstakil defterler veya diğer sicil defterlerini içinde dağınık hükümler şeklinde olduğunu belirtmektedir ${ }^{42}$. Buna örnek olarak Eskişehir Sivrihisar Ser'iyye Sicillerinin içinde 27 Zilkâde 1331/28 Ekim 1913 tarihli Kethüda Mahallesi'nde vefat eden Osman Efendi'nin küçük oğlu Süleyman Şükrü ve küçük kızı Emine'nin mallarından vasîleri Fatıma'ya borç vermesine dairdir. Verilen ana borç haricinde elde edilen 1780 kuruş ve 15 paranın çocukların sandığına eklendiği şöyle belirtilmiştir ${ }^{43}$.

Osmanlı Devleti'ndeki bu fonun yönetimi ve işleyişi noktasındaki düzen ise geçen zaman ve edinilen tecrübeler doğrultusunda yukarıda belirtilen nizamnamelerle sağlanmıştır ${ }^{44}$. Belli aralıklarla çıkarılan nizamnamelerde birçok konu detaylı şekilde düzene girmiş, yetim malının haksızlığa uğraması engellenmeye çalışılmıştır. Fakat hukuki olarak her ne kadar bu haksızlıklar engellenmeye çalış1lsa da eytâm sandıklarında birçok kişi görevlerinde usulsüzlükler yapmıştır.

7 Rebiülevvel 1268/31 Aralık 1851 tarihinde yayımlanan bu nizamnamede ${ }^{45}$. Haksızlık konusu teferruatlı kurallar ile hükme bağlanmıştır Bahsedilen nizamnamede daha ziyade para, kıymetli eşya, dükkân vs. veraset mallarından söz edildiği için toprak ile ilgili mallara değinilmemiştir. Bu eksikliği gidermek adına, 6 Rebiülâhir 1274/24 Kasım 1857 tarihinde yayımlanan nizamnameyle kendisine çiftlik, bağ, bahçe, değirmen ve bunların müştemilatı kalan yetimin mallarının, yetişkinlik çağına kadar uygun bir biçimde korunma ve çalıştırılması esaslarını düzenlemiştir ${ }^{46}$. Akabinde yayımlanan bir başka nizamname ise, taşra, kasaba ve köylerde oturan hak sahibi küçükler, akıl hastaları ve herhangi bir sebepten ötürü memleketinden uzakta bulunan Müslüman ve Gayr-î Müslimlerin mallarının koruma altına alınması ve çalıştırılması ile ilgilidir. Bu nizamnameyle merkezde bulunan yetimlerin mallarının düzenlenmesi taşralardaki yetimler için de geçerli olmuştur ${ }^{47}$.

21 Şaban 1291/3 Ekim 1874 tarihli 7 maddelik bir diğer düzenlemede ise Şeyhülislam bünyesinde yetim mallarıyla ilgilenecek bağımsız bir meclis kuruldu. Tam adı Meclis-i İdare-i Emvâl-i Eytâm olan meclis ile merkez ve taşralarda bulunan eytâm sandıkları tek bir çatı altında birleştirilerek başkanlığına Kadıaskerlik yapmış olan Şem'i Efendi getirildi. Ayrıca söz konusu meclis bünyesindeki ilmiye mensubu çalışanlarının dul ve yetimlerine maaş bağlamak amacıyla Muhtacin-i Eramil ve Eytâm-ı İlmiye Sandığı

${ }^{11}$ Cafer Çiftçi, "Osmanlı Döneminde Bursa'da Eytâm Keseleri”, Uludağ Üniversitesi Fen Edebiyat Fakültesi Sosyal Bilimler Dergisi 4/VI (2003): 83.

42 Özcan, a.g.e., 86. Tahsin Özcan, "Osmanlı Toplumunda Yetimlerin Himayesi ve Eytâm Sandıkları”, Istanbul Üniversitesi Ilahiyat Fakültesi Dergisi 14 (2006): 107-108.

${ }^{43}$ Ber vech-i bâlâ vasî ve medyûne-i mezbûre Fatıma Hatun'na ma'rifeti ve ma'rifet-i şer'le rü'yet olunan muhasebe de rüsum ve mesarif-i lâzımenin tenziliyle mütebâki 1780 kuruş 15 paraları beray-ı istirbah eytâm sanduğunda ibka olunduğu işbu mahalle zeylen tasdik kılındı. fi 27 Zilkade sene 331/fi 15 Teşrinievvel sene 329; BOA, MŞH.ŞSC.d.., hüküm: 24.

44 Özcan, “Osmanlı Toplumunda Yetimlerin...", 106.

45 Tertip 1, "Eytâm Nizamnâmesidir 1", 270-275.

46 Tertip 1, Cilt 4, 92.

${ }^{47}$ Tertip 1, "Memâlik-i Mahruse-i Şahânede Küşâd Olunacak... ", 276-281. 
kuruldu $^{48}$. Buna ilaveten İnfâk-ı Muhtâcin-î Eytâm ve Erâmil-î Ilmîye Nizamnamesi adıyla başka bir nizamname daha yayımlanmıştır ${ }^{49}$. Ardından yayımlanan nizamname ise telgraf ve posta memurları ile ketebe hademesinin emeklilik işlemleri ve bunların yetimlere bağlanacak maaşlarla ilgili ayrıntılı bilgi vermektedir $^{50}$. Zamanla değişen şartlar ve edinilen tecrübeler doğrultusunda 4 Rebiü'l-evvel 1324/28 Nisan 1906 tarihinde Emvâl-i Eytâm Müdürlüğü'nün işleyişini düzenleyen, 10 fasıl 117 maddelik bir nizamnâme daha yayımlanmıştır ${ }^{51}$. Emvâl-i Eytâm Müdürlüğü ve Eytâm Sandıkları hususunda yapılan düzenlemeler elbette bunlarla sınırlı değildir. Nizamnameleri detaylı şekilde incelemek dahi müstakil bir çalışmanın konusu olacaktır. Ama fonların işlemesiyle zikrettiğimiz nizamnameler, araştırmacılara bilgi sunacak mahiyettedir ${ }^{52}$.

1851 yılında belli nizamnamelerle düzene konulan eytâm sandıkları, Emvâl-i Eytâm Nezareti'nin altında taşrada da varlığını sürdürmüştür. 1908 yılında ise adı İdanat ${ }^{53}$ Sandĭ̆g olarak değiştirilmiştir. İlerleyen süreçte meydana gelen Balkan Savaşları, I. Dünya Savaşı ve Kurtuluş Savaşı'nın vermiş olduğu siyasi ve ekonomik sıkıntılardan dolayı İstanbul'daki İdanat Sandığı 28 Teşrinievvel 1336/ 28 Ekim 1920 tarihinden itibaren borç verme işlemine son vermiştir. Taşralardaki İdanat Sandıkları ise 1926 yılında çıkarılan Medeni Kanun'a kadar varlığını devam ettirmeye çalışmıştır. 1926 yılından sonra ise Eytâm ve Eramil Bankası kurulmuştur ${ }^{54}$.

\section{Eytâm Mallarına Yapılan Usulsüzlere Dair Bazı Örnekler}

Kur'an'da yetim mallarının korunması emrine riayet etmeyenlerin cezalandırılacağını belirten ayetlere ve Osmanlı Devleti'nin kesin hükümlerle yayımladıkları kurallara rağmen, her dönem yetim mallarında usulsüzlükler yapılabilmiştir. Bunların tespiti durumunda, yukarıda belirtilen nizamnameler ile devlet, tazmin veya telafi yoluna gitmiştir. Özellikle XIX. yüzyılda değişen vilayet sistemine bağlı olarak, eyaletlerde kurulan vilayet meclisleri, oluşan usulsüzlük için bir danışma organıyd ${ }^{55}$. Yetim malları üzerinde yapılan usulsüzlükler üzerine vereceğimiz örneklerin birçoğu, bu danışma organından Bâbıâli'ye rapor edilen durumlardir.

Eytâm sandıklarında emval-i eytâmın hesaplarını kontrol eden, yetim malları üzerindeki borç, faiz, vade, tahsilat gibi işlemleri denetleyen, rüşdünü ispat eden yetimlerin mallarını eksisiz şekilde iade eden görevli eytâm müdürüdür ${ }^{56}$. Eytâm müdürünün yetim malı üzerinde yapacağı muameleleri yayımlanan nizamnamede ${ }^{57}$ detaylı şekilde incelemek mümkündür.

Yapılan usulsüzlüklerin birçoğunda eytâm müdürlerinin adı geçmektedir. Bunlara örnek vermek gerekirse; Lâpseki Kazası'ında eytâm eski müdürü Ahmed Efendi, Lâpseki Banıca(?) şubesinin başkanı tayin edildikten sonra eski görevi süresinde Hacı Ali Ağa'nın terekesinden bazı eşyaları düşük fiyatla ithal

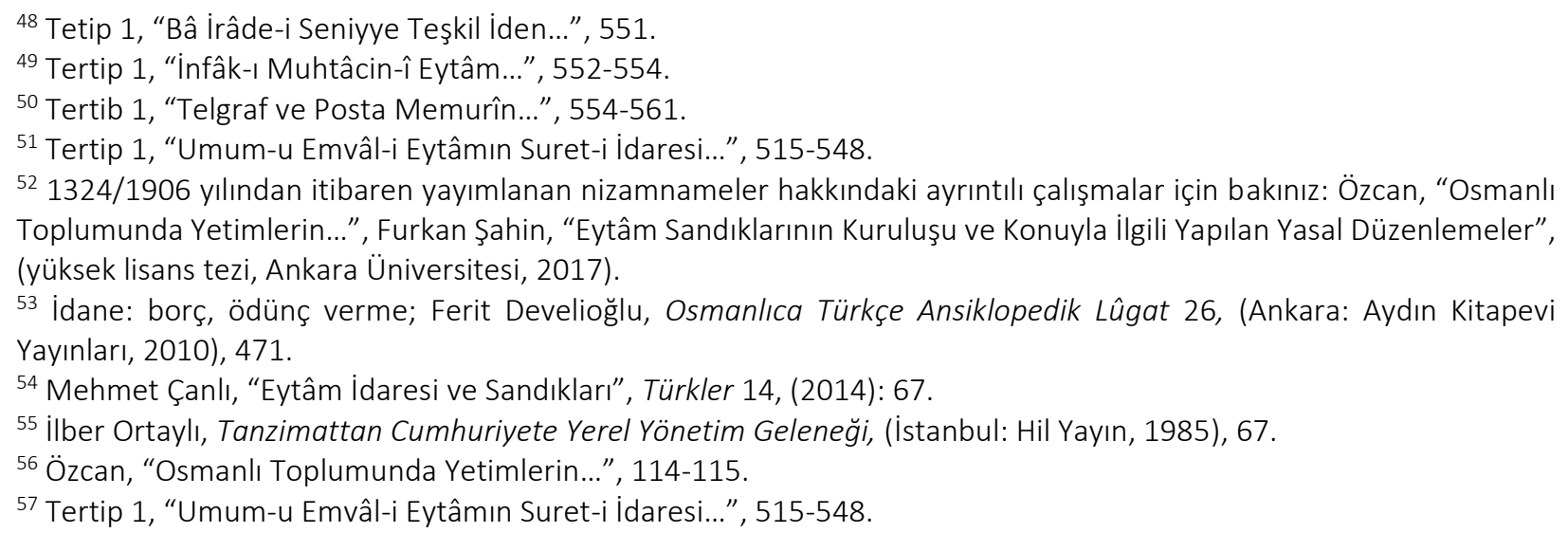


ettirdiğine, bazısının da kendisinin kullandığına dair iddia üzerine konu bölge kaymakamlığından meşihata bildirilmiştir $^{58}$. Eytâm Ahmet Efendi'nin Hacı Ali Ağanın terekesinden kalan malları gizlediği, yetimler için yapılan nemaları zayi ettiği Biga Mutasarrıflığına bildirilmiştir ${ }^{59}$. Usulsüzlüğe dair tespitler ve muhtemelen tanzim husus kayda geçmiş olmasına rağmen Ahmed Efendi'ye ilaveten bir ceza verilip verilmediği sicile yansımamıştır.

Eytâm Sandıklarından sandığı idare eden müdürlere ve çalışan memurlara borç verildiği de vakidir. Para ihtiyacında olup sandığa başvuran sıradan bir kişi, parayı alıp borcunu tahsil etmeden herhangi bir kuruma memur olarak tayin edilirse, yeni işinden aldığı maaşla borcu tahsil edilirdi. $\mathrm{Bu}$ duruma vereceğimiz örnek ise emvâl-i eytâmdan borç para alan ve bunu ödemeyen Osman Ziya Bey'in, bir süre sonra Emniyet Sandığı'na memur olarak tayin edildiği öğrenilmiş, bu bilgi üzerine Emvâl-i Eytâm Müdiriyyeti, Emniyyeti Umumiyye Müdiriyeti'ne bir istid'a göndererek Osman Ziya Bey'in maaşından 25 Ramazan 1322/3 Aralık 1904 tarihinden itibaren 287 kuruş tahsil edilmesini istemiştir ${ }^{60}$.

Eytâm mallarına herhangi bir şekilde usulsüzlük yapan eytâm müdürleri Şûrây-1 Devlet tarafından yargılanmaktaydı. Yapılacak muhakemede yetimin hakkını müdafaa etmek amacıyla meşihat tarafından yetime bir vekil tayin edilmekteydi ${ }^{61}$. Örneğin yetim malından zimmetine 100.000 kuruşun üzerinde para geçirmekle suçlanan Şam eski eytâm müdürü Arif Efendi'nin yargılanmak üzere Suriye Vilayeti'ne gönderileceği, 2 Cemaziyelahir 1322/14 Ağustos 1904 tarihinde şûra-yı devlet reisi tarafından şu şekilde kayda geçmiştir; Emvâl-i Eytâmdan zimmetine akçe geçürdiğ̈̈ iddiastyla taht-ı mahkemeye alınan Şam Eytâm Müdürü Sabık Arif Efendi hakkında Şura-yı devlet İstinaf Mahkemesince virilen hüküm katiyyete kesb etmiş ve ol babda tanzim kılınan i'lam leffen takdim huzur-l sami-i cenabı sadaret penahileri kllınmış olmağla Suriye vilayetine tebliğ idilmek üzere Dahiliye Nezareti celilesine havale buyrulması bâbında emrû fermân hâzret-î menlehülemrindir ${ }^{62}$.

Eytâm sandıklarındaki paralarla ilgili usulsüzlükler yalnızca müdürlerin bu paraları alması ya da habersizce kullanmasından ibaret değildi. Yetime ait sandığın yerini bilen müdürler dışındaki kişiler de bu mallardan istifade etmiştir. Örneğin Silivri eytâm sandığının müdürü Ahmed Efendi, 16 Kânunuevvel 1335/16 Aralık 1919 tarihinde Dahiliye Nezareti'ne gönderdiği dilekçede odasındaki eytâm sandığının zorlanarak açıldığını ve içerisinden 8106 lira kadar bir paranın alındığını beyan etmiş ve tahkikata hemen başlandığını, neticenin bildirileceğini de eklemiştir ${ }^{63}$.

Eytâm mallarına yapılan usulsüzlüklerde pek çok eytâm müdürünün adı geçmekle beraber farklı devlet memurlarının ve vasi olarak belirlenen kişilerin isimlerine de rastlamaktayız. Örneğin Eski Musul Valisi Tahir Paşa, bölgedeki redif zabıtaları ile bazı diğer memurların, yetim ve emekli maaşlarında suiistimaller yaptıklarına dair bilgi üzerine tahkikat yapılması istemiştir. ${ }^{64}$.

Arşiv vesikalarında yetimlerin mallarını korumakla görevli vasilerin isimleri ve yanlışları da mevcuttur. 18 Rebiülahir 1325/31 Mayıs 1907 tarihli arşiv vesikasında, Manastır'da ikame eden yetimin

\footnotetext{
58 BOA, DH, MKT, n. 1823-117, 1-2.

${ }^{59}$ BOA, DH, MKT, n. 1848-46, 1.

${ }^{60}$ BOA, DH, EUM, THR, n. 17-9, 5.

61 BOA, BEO, n. 1533-114951, 1.

62 BOA, DH, MKT, n. 868-69, 1.

63 BOA, DH, EUM, AYŞ, n. 28-11, 1.

${ }^{64}$ BOA, DH, MKT, n. 1961-68, 1.
} 
vasîsi Feride Hanım, yetime ait olan eve müdahale etmesi üzerine yargılanmıştır. Manastır İstinaf Mahkemesi'ne yazılan dilekçede ${ }^{65}$ durum anlaşılmaktadır.

Osmanlı Devleti'nin yetim malları üzerindeki hassasiyetini göstermek adına verilebicek örnek ise; Musul Eytâm Sandığı muamelatının birçok suiistimale uğratıldığından bahisle bölge Eytâm Sandığı müdürünün hemen değiştirilmesi kararlaştırılmıştır. Ayrıca vilayet meclisinde bir komisyon teşkil edilerek durumun incelenmesi ve görevi sonlandırılan müdürün yerine başka birinin tayini istenmiştir ${ }^{66}$.

Tarihin her döneminde olduğu gibi, Osmanlı Devleti'nin Eytâm Sandıkları'nı oluşturduğu XIX. yüzyılda da yetim malına usulsüzlükler yapılmıştır. Dinî ve dünyevî ihtarlara rağmen yetim malına yapılan usulsüzlüklere karşı alınan kanuni ve adli önlemler yürürlüğe koyulmuştur.

\section{Sonuç}

Kur'an-1 Kerim'de yetimlerle ilgili ayetlerde onlara iyi davranmak, güzel söz söylemek, onları doyurmak ve onlara yardımcı olmak öğütlenir. Bunun yanında yetimlere mallarının verilmesi, onların haklarının yenilmemesi ve özellikle onlara adaletli davranılması gerektiği belirtilmektedir. Hz. Muhammed (s.a.s)'in de yetim ve öksüz olması da büyük bir etkendir. Bu ayetler bize göstermektedir ki, İslam dini toplumda sosyal dayanışmayı, sosyo-ekonomik olarak alt tabakada bulunan kişilere ulaşıp her türlü desteği vermeyi hedeflemektedir.

İslam dini, kimsesiz çocukların bakımını kamuya yüklemektedir. Devletin toplumsal huzuru sağlamasındaki yol, şüphesiz bakıma muhtaç fertlerin huzurlarının sağlanmasıyla doğru orantılıdır. İşte yetim ve kimsesizleri korumak ve bakımlarını sağlamak amacıyla ecdadımız, Darüşşafaka, Darüleytâm, Eytâm Sandıkları ve Emvâl-i Eytâm Nezareti gibi pek çok müessese oluşturarak hedefleri kurumsallaştırmıştır.

Osmanlı Devleti'nin yetim ve öksüz çocukların ebeveynlerinden kalan mallarını muhafaza ve işletmesi durumu bugün dahi benzeri olmayan, her yönüyle teşkilatlı bir fondur. Gerek söz konusu çocukların gelecekteki hayatlarını düzene sokma, gerekse devlet ekonomisini canlı tutmak amacıyla tercih edilen bu yöntem şüphesiz Osmanlı Devleti’nin karakteristik ekonomi anlayışından ve İslam dininin yetim ve öksüz çocuklara verdiği ihtimamdan ileri gelmektedir.

Osmanlı Devleti'nin yönetimi boyunca zaman zaman yetimlere ait malların usulsüz kullanımı mevcuttur. Devlet, muhtelif tarihlerde çıkardığı nizamnamelerle bu durumun önüne geçmeye çalışmıştır. Yetimlere ait malların işletilmesi usulü, iktisat tarihçilerinin geniş kapsamlı çalışma alanı olmasıyla birlikte konu hakkında daha detaylı araştırılma yapılması gerekmektedir.

\footnotetext{
65 BOA, TFR. I, MN, n. 126-12547, 1-2-3.

${ }^{66}$ BOA, BEO, n. 83-6216, 2.
} 


\section{Kaynakça}

\section{Arşiv Vesikaları}

BOA, BEO, 1533-114951.

BOA, BEO, 83-6216.

BOA, DH, EUM, AYŞ, 28-11.

BOA, DH, MKT, 1823-117.

BOA, DH, MKT, 1848-46.

BOA, DH, MKT, 1961-68.

BOA, DH, MKT, 868-69.

BOA, EUM, THR, 17-9.

BOA, MŞH, ŞSC.d.., 7940.

BOA, TFR.I., MN, 126-12547.

\section{Diğer Kaynaklar}

Akyüz, Vecdi. "Kur'an ve Sünnette Ebeveyn ve Çocuk Hakları”, Kur'ân ve Sünnete Göre Temel İnsan Hakları, İsmail Kurt ve Seyid Ali Tüz. İstanbul: Ensar Neşriyat, 2014.

Ar1, Abdüsselam. "Yetim”, Diyanet Vakf1 İslam Ansiklopedisi, XLIII (İstanbul 2013), ss. 501-503.

Ayral, Mehmet Şirin. “Kur'an’ın Yetimlere Bakış Açısı”, Yüksek lisans tezi, Selçuk Üniversitesi, 2007.

Bardakoğlu, Ali. "Hidâne”, Diyanet Vakfi İslam AnsiklopedisNi, XVII (İstanbul1998), ss. 467-471.

Bozkurt, Fatih. "Yetimi Kolla, Malını Koru! Tereke Defterleri Ve Yetim Malları (1785-1875)", Trakya Üniversitesi Edebiyat Fakültesi Dergisi, 3, (2012): 69-90.

Buhârî, Sahîh. Muhtasarı Tecrîd-i Sarîh,.Çev., Abdullah Feyzi Kocaer, İstanbul: Turkuaz, 2013.

Coşar, Asiye Mevhibe. "Türk Söz Varlığında “Öksüz” ve "Yetim” Kavramları”, Savaş Çocukları, Öksüzler ve Yetimler, İstanbul: Kişisel Yayınevi, 2003.

Çanlı, Mehmet. "Eytâm İdaresi ve Sandıkları ve Osmanlı Devleti'nde Yetimlerin Ekonomik Haklarının Korunması", Savaş Çocuklart: Öksüzler ve Yetimler, bs., Emine Gürsoy-Naskali, Aylin Koç, İstanbul: Kişisel Yayınları, 2003.

Çanl1, Mehmet. "Eytâm İdaresi ve Sandıkları", Türkler 14, (2002): ss. 57-74.

Çiftçi, Cafer. “Osmanlı Döneminde Bursa'da Eytâm Keseleri”, Uludă̆ Üniversitesi Fen Edebiyat Fakültesi Sosyal Bilimler Dergisi 4/VI, (2003): ss. 81-96.

Demirci, Muhsin. “Açılış Konuşmaları”, Kur'ân ve Sünnete Göre Temel İnsan Hakları, İsmail Kurt ve Seyit Ali Tüz. İstanbul: Ensar Neşriyat, 2014.

Develioğlu, Ferit. Osmanlıca Türkçe Ansiklopedik Lûgat 26, Ankara: Aydın Kitapevi Yayınları, 2010.

Düstur, Tertip 1. "Eytâm Nizamnâmesidir” ss. 270-275.

Düstur, Tertip 1. "İnfâk-1 Muhtâcin-î Eytâm ve Erâmil-î İlmîye Nizamnâmesidir”, ss. 552-554. 
Düstur, Tertip 1. "Memâlik-i Mahruse-i Şahânede Küşâd Olunacak Eytâm Sandıklarının Sûret-î İdâre ve Muhafazâsı Hakkında Nizamnâme ” ss. 276-281.

Düstur, Tertip 1. "Telgraf ve Posta Memurîn ve Ketebe Hademesinden Tekâüde Şâyeste Bulunanların Derece-i İstihkâklarına ve Bunların Eytâm ve Erâmilinin Mertebe-i İhtiyâclarına Göre Tahsis Kılınacak Maaşlar ve Buna Karşılık Tutulacak Mebâliğin İdâre-i Mahsûsasına ve Bu Bâbda Lâzım Gelen Muâmelâta Dair Nizamnâmedir ”, III, ss. 554-561.

Düstur, Tertip 1. "Umum-u Emvâl-i Eytâmın Suret-i İdaresi Hakkında Tadilen Kaleme Alınan Nizamnamedir", VIII, ss. 515-548.

Düstur, Tetip 1. "Bâ İrâde-i Seniyye Teşkil İden Meclis-i İdâre-i Emvâl-i Eytâmın Sûret-i Teşkîlini ve Vezâifini Mübeyyin Nizâmnâmedir ”,III, ss. 551.

Ekşi, Ahmet. Şer'iyye Sicilleri Örneğinde İslâm Hukuku Bakımından Evlat Edinme, (İstanbul: Ensar Neşriyat, 2019).

Eryüksel, Ahmet, “'Osmanlı Devleti’nde Dul ve Yetimler', Şarkiyat Mecmuası, VIII, (1998): ss. 331-344.

Hızal, İsmail. "İlk Sosyal Güvenlik Birimlerinden Eytâm Sandıkları”, IV. Afyonkarahisar Araştırmaları Seтроzуити Bildirileri, 29-30 Eylül 1995.

İnanç, Veli. "Eytâm İdaresi-Sandıkları ve Marmaris Örneği (1885-1911)" Yüksek lisans tezi, Muğla Üniversitesi, 2002.

Kızıldağ, Necla. "Eytâm İdaresi ve 50 Nolu Eskişehir-Sivrihisar İdanat Sandığg Defterinin Transkripsiyonu ve Değerlendirmesi." Yüksek lisans tezi, Afyon Kocatepe Üniversitesi, 2019.

Köse, Saffet. "Rüşd”, Diyanet Vakfi İslam Ansiklopedisi, XXXIV (İstanbul 2008), ss. 298-300.

Kutup, Seyyid. Fi Zilal 'il-Kur'ân 14, çev., Mehmet Emin Saraç, İsmail Hakkı Şengüler ve Bekir Karlaăa, İstanbul: Hikmet Yayınları, 1979.

Ortayl1, İlber. Tanzimattan Cumhuriyete Yerel Yönetim Geleneği, İstanbul: Hil Yayın, 1985.

Özcan, Tahsin. “Osmanlı Toplumunda Yetimlerin Himayesi ve Eytâm Sandıkları”, İstanbul Üniversitesi Ilahiyat Fakültesi Dergisi 14, (2006): ss. 103-121.

Özcan, Tahsin. "Osmanlı Yetiminin Hamisi”, Yoksulluk 3, İstanbul: Deniz Feneri Yayınları 2003.

Özcan, Tahsin. Osmanlı Para Vakıfları: Kanûnî Dönemi Üsküdar Örneği, Ankara: Türk Tarih Kurumu Yayınlar1, 2003.

Özsoy, Ömer. Güler, İlhami. Konularına Göre Kur'an (Sistematik Kur'an Fihristi), Ankara: Fecr, 2017.

Şahin, Furkan. "Eytâm Sandıklarının Kuruluşu ve Konuyla İlgili Yapılan Yasal Düzenlemeler.” Yüksek lisans tezi, Ankara Üniversitesi, 2017.

Ünal, İrfan. “167 Nolu Çanakkale Eytâm Sandığına Mahsus Teminatlı İdâne Defteri’nin Transkripsiyonu ve Değerlendirmesi (1920-1926)" Yüksek lisans tezi, Çanakkale On Sekiz Mart Üniversitesi, 2010.

Yazıcı, Nesimi. "Osmanlılarda Yetimlerin Korunması Üzerine Bazı Değerlendirmeler”, Ankara Üniversitesi İlahiyat Fakültesi Dergisi 48/I (2007): ss. 1-46.

Yıldız, Abdullah Taha. "Kâtip Seyyid Mehmet Nuri Efendi'nin Eytâm Sicillerine Göre Osmanlılarda Yetim Mallarının İdaresi”, Yüksek lisans tezi, Marmara Üniversitesi, 2017. 